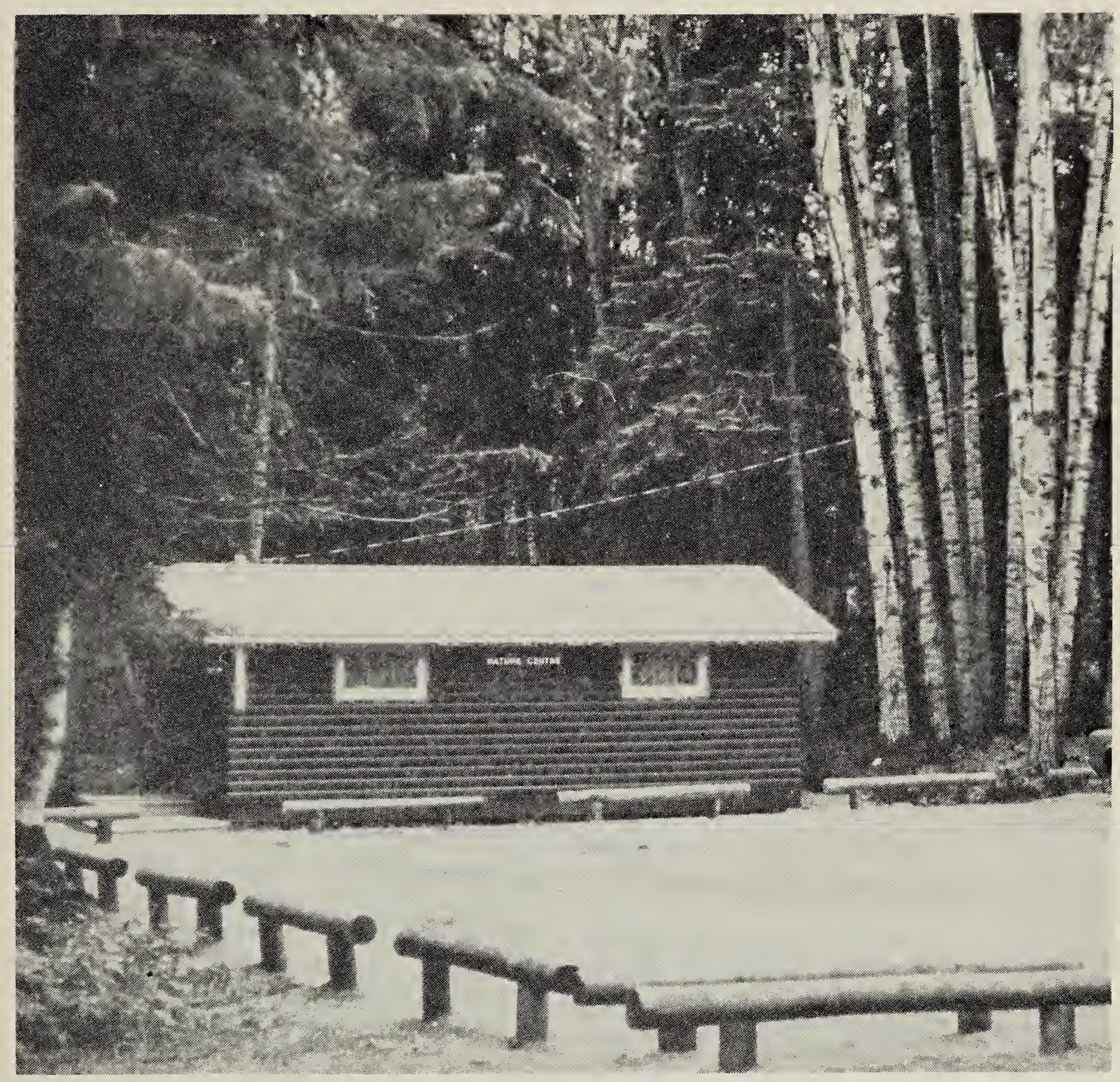

Duck Mountain Provincial Park Nature Centre.

R.J. Long

\title{
GOLDEN-WINGED WARBLER AT DUCK MOUNTAIN, SASKATCHEWAN
}

STAN SHADICK, 3F-1800 Main Street, Saskatoon, Saskatchewan. S7H 4B3

I am one of those who finds observing warblers to be the epitome of birdwatching. It is true, these tiny birds present a challenge to the birder because of their flirtive behavior - often flying out of sight in the woods as soon as they are spotted on an exposed perch. Nevertheless, if one is persistent and quick, the view of their bold colourful plumages is a just reward. As a group they must surely display nature's artistry at its best.

In the Saskatoon district warbler watching is primarily restricted to August and 
- early September when mainly dullplumaged birds may be found in our city parks and residential areas. During spring migration only a few species are in abundance - primarily Yellow-rumped, Orange-crowned, Tennessee and Yellow Warblers.

In order to seek out a wider variety of warblers, one must travel to their nesting grounds in the transition zone from aspen parkland to boreal forest. With this in mind, I joined a group of Saskatoon Natural History Society members who visited Duck Mountain Provincial Park 28-30 May 1986 while en route to the Yorkton Spring Meet.

I was fascinated by the brilliant orangefaced Blackburnian Warblers which were one of the most abundant warblers in the park. Nashville Warblers were also quite common which surprised me as I have found them to be extremely rare elsewhere in the province.

On 29 May our group had spent the morning birding along the road to Little Boggy Creek near the south park boundary. As we drove up a steep hill, only $2 \mathrm{~km}$ from Manitoba, I heard a different buzzy song - BIZZ, BUZZ, BUZZ, BUZZ, $B \cup Z Z$. I recognized this song to be that of a Golden-winged Warbler, a bird I had previously known from southern Ontario. As I tramped through the woods, the bird flew to a dead branch where it sat showing off its yellow crown, black face, white belly and yellow patch on its grey wings. The bird continued to sing from this spot for 15 minutes while it was also observed by Mary Gilliland, Jim \&
Vivian Slimmon, Paul \& Vi Coutu, Ron \& Muriel Bremner, Alvena Schnell, Phil \& Monique Thair, Marie Gillespie, Jean Anderson, Pern Cordery and Frank Roy.

The next morning we returned to the spot in hopes of showing the bird to Bernie and Win Anderson. Sure enough! It was still there singing from the same dead branch. In fact, it sat there long enough for us to observe it with a spotting scope.

The bird continued to sing from the same territory throughout the first half of June where it was observed on frequent occasions by Nigel Caulkett, the park naturalist and other visiting birders.

Golden-winged Warblers have been reported from nearby Riding Mountain National Park in Manitoba for several years. ${ }^{3}$ This sighting is the first record for Duck Mountain Provincial Park and only the fifth published record for Saskatchewan. Previous Saskatchewan records include sightings in Regina 18 May 1962, 2 June 1968 and 1 October 1972; as well as a sighting in the Porcupine Hills, 45 $\mathrm{km}$ east of Hudson Bay, 17 June, 1984. ${ }^{2}$ The Duck Mountain sighting is the only case where a bird was observed on the same territory for more than one day.

'BELCHER, M. 1980. Birds of Regina. Sask. Nat. Hist. Soc., Spec. Publ. 12. p. 106.

${ }^{2}$ GOLLOP, J.B. 1984. Prairie Provinces Region. Am. Birds 38:1031.

${ }^{3}$ WALLEY, W.J. 1973. A study of seven warblers in Riding Mountain National Park, Manitoba. Blue Jay 31:158-166. 